ZatącZ्विil

\title{
IKONOLOGIA CIERPIENIA. ABY WARBURG O SYMBOLIZACJI OBRAZOWEJ I OBRAZACH WOJNY
}

ROBERT PAWLIK

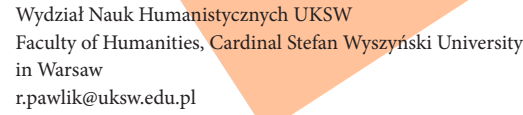

Wydział Nauk Humanistycznych UKSW in Warsaw

r.pawlik@uksw.edu.pl

W 2003 roku Susan Sontag opublikowała swą ostatnią książkę Widok cudzego cierpienia ${ }^{1}$. Omówiła w niej zdolność fotografii wojennej, najbardziej realistycznej formy reprezentacji przemocy, do mobilizacji antywojennej opozycji. W swym eseju autorka wspomniała także o przedstawieniach okrucieństw wojennych w zachodnim malarstwie, jak również o zachodniej „ikonografii cierpienia” 2 . W jej erudycyjnym wywodzie brak jednak wzmianki o Abym Warburgu (1866-1929), pionierze refleksji nad obrazami w kontekście zagadnienia cierpienia. W tym miejscu chciałbym krótko przypomnieć Warburgiańską koncepcję obrazu oraz zasygnalizować jego wkład w badania nad wizualnym wymiarem wojny.

1.

Aby Warburg wyszedł od tradycyjnie pojętej historii sztuki, większość opublikowanych prac poświęcając artystom wczesnego renesansu, w szczególności ich zależności od grecko-rzymskiego antyku³; jednakże tę historię sztuki Warburg przekroczył na rzecz antropologicznie ukierunkowanych

${ }^{1}$ S. Sontag, Widok cudzego cierpienia, tłum. S. Magala, Kraków 2010.

2 Ibidem, s. 51.

3 Ich reprezentatywny wybór w języku polskim: A. Warburg, Narodziny Wenus $i$ inne szkice renesansowe, tłum. R. Kasperowicz, Gdańsk 2010. Zob. też: idem, Obrazy z terytorium Indian Pueblo w Ameryce Północnej, tłum. P. Sosnowska, „Konteksty” 2011, nr 2-3, s. 41-54; idem, Atlas obrazów Mnemosyne, tłum. P. Brożyński i M. Jędrzejczyk, Warszawa 2015. 
badań nad wizerunkami. Wyszedł zatem poza „arcydzieła”, analizowane w perspektywie formalnej czy estetycznej, by skupić się na „wizerunkach” w ich funkcji biologicznej i społecznej. Obrazy interesowały go nie tyle jako odpowiedź na „wrodzoną” człowiekowi potrzebę piękna, ile jako pierwotna forma ludzkiej reakcji na świat, to jest - kluczowe narzędzie przetrwania i orientacji ${ }^{4}$.

W stosunku do historii sztuki Warburg znacząco poszerzył pole zainteresowań badawczych. Zajmowały go obiekty, które na przełomie XIX i XX wieku rzadko lub wcale nie były poddawane namysłowi znawców czy badaczy sztuki. Należały do nich między innymi znaczki pocztowe, fotografie prasowe i reklamowe, arrasy, figury wotywne, figury woskowe, mapy, w tym zwłaszcza mapy nieba. Badanie wizerunków nie stanowiło też dla hamburskiego uczonego celu samego w sobie. Miało dostarczać podstawy dla nowej dyscypliny badawczej - kompleksowej „nauki o kulturze”.

Warburgiańska Kulturwissenschaft nawiązywała do projektu nakreślonego przez Giambattistę Vica w Nauce nowej5. Projekt ten na gruncie filologii niemieckiej podjął i rozwinął Hermann Usener - jeden z nauczycieli Warburga, na którego wykłady na Uniwersytecie w Bonn uczęszczał on w latach $1886-1887^{6}$. Ambicją tak pojętego kulturoznawstwa było dotarcie do prawdy o człowieku poprzez analizę jego wytworów. Różnica między Vikiem i Usenerem, z jednej strony, a Warburgiem, z drugiej, polegała na tym, że dla tych pierwszych ludzkim „wytworem” gwarantującym uprzy-

${ }^{4} \mathrm{Na}$ temat Warburga zob. E. Gombrich, Aby Warburg. An Intellectual Biography, London 1970; J. Białostocki, Posłanie Aby M. Warburga: Historia sztuki czy historia kultury?, [w:] idem, Refleksje i syntezy, Warszawa 1987, s. 187-203; J. Szczuka, Mnemosyne. Sztuka jako organ społecznej pamięci w pismach Aby Warburga, „Roczniki Humanistyczne” 1998, z. XLVI, s. 137-149; W. Bałus, Dlaczego Warburg?, „Przegląd Kulturoznawczy” 2010, nr 2, s. 25-52; monograficzny numer „Kontekstów” (2011, nr 2-3); G. Didi-Huberman, Tragedia kultury: Warburg i Nietzsche, tłum. K. Jóźwiak, „Kronos” 2015, nr 3, s. 278-294.

5 G. Vico, Nauka nowa, tłum. J. Jakubowicz, Warszawa 1966.

6 E. Gombrich, op. cit., s. 26-30. Zob. też: R. Kany, Hermann Usener as Historian of Religion, „Archiv für Religionsgeschichte” 2004, Bd. 6, s. 159-176; idem, Mnemosyne als Programm. Geschichte, Erinnerung und die Andacht zum Unbedeutenden im Werk von Usener, Warburg und Benjamin, Tübingen 1987. 
wilejowany wgląd w rzeczywistość mondo civile był język, to jest nazwy, metafory, mity; dla drugiego zaś były nim obrazy. $Z$ tego powodu pierwsi za właściwą metodę kulturoznawstwa uznali filologię (zwłaszcza etymologię), drugi - badanie wizerunków („ikonologię”) 7 .

Podobnie jak jego prekursorzy, Warburg stosował historyczno-psychologiczną metodę wyjaśniania, wychodząc od specyficznej sytuacji człowieka pierwotnego, którego byt, w porównaniu do reszty istot żywych, odznaczał się fundamentalnym niedopasowaniem do otoczenia. Pozbawiony sierści, pazurów, silnego instynktu etc., człowiek jawił się jako istota „naga”. „Niedoposażony”, w obliczu wrogich żywiołów odczuwał głęboką trwogę. Toteż podstawowym faktem determinującym kondycję człowieka był obezwładniający lęk, stanowiący elementarną odpowiedź na to, co w świecie nieznane i potencjalnie groźne. Szczególnego powodu do trwogi dostarczał rozświetlany błyskawicami i rozdzierany hukiem grzmotów - firmament ${ }^{9}$. To, że większości religijnych panteonów przewodzą bóstwa nieba - gromo-

7 Wyrażenie „analiza ikonologiczna” pojawia się po raz pierwszy w pracy Warburga Sztuka Italii i astrologia międzynarodowa $w$ Palazzo Schifanoia w Ferrarze", [w:] idem, Narodziny Wenus..., op. cit., s. 212. Stała się znana dzięki pracy E. Panofsky’ego, Ikonografia i ikonologia, tłum. K. Kamińska, [w:] idem, Studia z historii sztuki, Warszawa 1971, s. 11-32.

8 Tradycja refleksji nad człowiekiem jako „bytem wybrakowanym” sięga Demokryta i Protagorasa. Jej najpełniejsze przedstawienie znajdujemy w micie Prometeusza z Protagorasa Platona (320d-322d) oraz u J.G. Herdera, Rozprawa o pochodzeniu języka, tłum. B. Płaczkowska, [w:] idem, Wybór pism, Wrocław 1988, s. 59-175. Zob. A. Bielik-Robson, „Homo anxius”. Nowoczesność, czyli eksodus $z$ lęku, „ER(R)GO. Teoria - Literatura - Kultura” 2014, nr 29, s. 9-23.

9 W znanym fragmencie Nauki nowej Vico powiada: „Ludzie pierwotni narodów pogańskich, niby dzieci rodzącej się ludzkości [...], tworzyli pod wpływem na wskroś zmysłowej wyobraźni [...]. Kiedy niebo nareszcie rozbłysło i zagrzmiało wśród straszliwych huków i błyskawic, [...] wówczas to [...] przerażeni i osłupiali wobec nieznanego zjawiska, spojrzeli w górę i dostrzegli niebo. [...] Wyobrazili sobie niebo jako ogromne żywe ciało i dlatego nazwali je Jowiszem. Był to pierwszy bóg, [...] który za pośrednictwem błyskawic i łoskotu gromu chciał do nich przemówić”. G. Vico, op. cit., fragmenty 376-377. Zob. też: H. Usener, Kereunos, Ein Beitrag Religiöser Begriffsgeschichte, „Rheinisches Museum Für Philologie” 1905, Bd. 60, s. 1-30. 
władny Zeus, ciskający pioruny Jowisz czy Baal - już Vico uznał za dowód, iż tam właśnie znajdowało się praźródło ludzkiego niepokoju. Jednakże ów animalny lęk pierwszego człowieka stanowił zarazem potężną siłę kulturotwórczą. Skoro opanowanie lęku było głównym wyzwaniem, przed którym stał człowiek, to wszystkie wynalazki cywilizacyjne należy uznać za „odpowiedź" na to wyzwanie. Są one „protezami”, umożliwiającymi skompensowanie naturalnych ludzkich braków, oraz instrumentami radzenia sobie $\mathrm{z}$ lękiem.

Usener w tych kategoriach wyjaśniał funkcję języka. Nazwy bogów wyprowadził ze skrajnych reakcji emocjonalnych człowieka, to jest z dźwięków wydawanych w momencie paroksyzmu trwogi ${ }^{10}$. Głosy ludzi owładniętych przerażeniem na widok błyskawicy utrwalały się w imiona pierwszych bóstw ${ }^{11}$. Były one zatem - w pojęciu Usenera - „zakrzepłymi” doświadczeniami grozy. Toteż, z jednej strony, nazwy bóstw odnosiły się do źródła traumy, zachowując w sobie ślad pierwotnych bolesnych doznań, z drugiej jednak - przywoływanie owych imion okazywało się pomocne w opanowywaniu przerażenia. Taki efekt miały zresztą wszystkie nazwy - w myśl zasady, że to, co posiada imię, nie jest już całkiem obce.

W analogiczny sposób Warburg pojmował rolę symbolizacji obrazowej. Uchwycenie w obrazie „odruchu fobicznego”, owej pierwotnej reakcji człowieka na świat, przeobraziło bezpostaciowy lęk w strach przed czymś konkretnym, co można „pokazać”. W konsekwencji zmierzenie się z reakcją grozy przez obrazowe pochwycenie źródła lęku umożliwiało oddzielenie się podmiotu od tego doznania. W lękowej kondycji pierwotnego człowieka akt symbolizacji obrazowej jawi się zatem jako upostaciowienie traumatycznego przeżycia pomocne w dystansowaniu się wobec niego, a pośrednio również

10 Usener polemizował z koncepcją Vica, który wyprowadzał nazwy bogów z imitacji odgłosów grzmotu i błyskawicy: „Wraz z powstaniem boskiego symbolu Jowisza [...] zaczął również tworzyć się język artykułowany dzięki onomatopei. [...]. Owego Jowisza Latynowie zwali początkowo od huku grzmotów Ious, Grecy, od błysku pioruna Zcúc". G. Vico, op. cit., fragment 447.

${ }^{11}$ Najbardziej znana teoria Usenera mówi o Augenblicksgötter, „bóstwach chwili”, które objawiają się tylko raz przy jakiejś okazji i z tejże okazji wywodzą swe imię. Zob. H. Usener, Götternamen, Versuch einer Lehre von der religiösen Begriffsbildung, Bonn 1896. 
wobec świata. Innymi słowy, symbolizacja obrazowa wytwarza „przestrzeń myślową" między podmiotem a przedmiotem, między „ja” a światem ${ }^{12}$. Do tego właśnie sprowadza się główny cel antropologicznie pojętej kultury. W jednym z ostatnich swych pism, wstępie do Atlasu obrazów Mnemosyne, hamburski uczony stwierdził: „świadome wytworzenie dystansu pomiędzy sobą a światem zewnętrznym określić należy jako podstawowy akt ludzkiej cywilizacji”"13. Kultura oznacza zatem wydobywanie się człowieka z pierwotnego „zanurzenia” w świecie i konstytuowanie się jako świadomego swych granic podmiotu - jednostki stojącej w opozycji wobec świata ${ }^{14}$.

Kulturową rolę wizerunków dobrze ilustrują astrologiczne mapy nieba - obiekt wieloletniej fascynacji intelektualnej Warburga ${ }^{15}$. Tworzone już w starożytnej Babilonii, nie były wyłącznie owocem bezinteresownej kontemplacji, lecz czynnikiem przepracowywania „traumy nieba” oraz sposobem na uzyskiwanie nad nim kontroli. Gdy na rozgwieżdżonym nocnym nieboskłonie wyodrębniono pierwsze konstelacje - to znaczy gdy w rozrzuconych świetlistych punktach dopatrzono się sensownego zarysu postaci - wówczas niebo, źródło panicznej trwogi, zostało przeobrażone w konkretne i uchwytne obrazy: konstelacje gwiezdne. Porządkując chaos rozgwieżdżonego nieba, wizerunki te oswajały je, obniżając poziom ludzkiego lęku. Jednak oddziaływanie tych wizerunków miało charakter nie

12 „Myśl mityczna i myśl symboliczna w wysiłku uduchowienia relacji między człowiekiem a otaczającym go światem tworzą dystans jako przestrzeń modlitwy lub przestrzeń namysłu [Denkraum]". A. Warburg, Obrazy $z$ terytorium Indian Pueblo..., op. cit., s. 54.

13 A. Warburg, Wprowadzenie, [w:] idem, Atlas obrazów Mnemosyne, op. cit., s. 2.

14 Szerzej na ten temat: J. Habermas, Wyzwalająca moc symbolicznego formowania. Humanistyczne dziedzictwo Ernsta Cassirera i Biblioteka Warburga, [w:] idem, Od wrażenia zmysłowego do symbolicznego wyrazu, tłum. K. Krzemieniowa, Warszawa 2004, s. 5-33.

15 Zob. A. Warburg, Sztuka Italii i astrologia międzynarodowa $w$ Palazzo Schifanoia w Ferrarze, [w:] idem, Narodziny Wenus..., op. cit., s. 191-216; idem, Die Einwirkung der Sphaera barbarica auf die kosmischen Orientierungsversuche des Abendlandes, [w:] idem, „Per monstra ad sphaeram”. Sternglaube und Bilddeutung. Vortrag in Gedenken an Franz Boll und andere Schriften 1923 bis 1925, hrsg. D. Stimilli, C. Wedepohl, München - Hamburg 2008, s. 63-143. 
tylko psychologiczny - jako pomoc w mierzeniu czasu (np. przy opracowywaniu kalendarzy) i wyznaczaniu kierunku, mapy nieba stały się nieodzowne między innymi $\mathrm{w}$ rolnictwie i nawigacji. Ich rola $\mathrm{w}$ orientacji człowieka w czasie i przestrzeni była dla Warburga emblematem fundamentalnego wkładu obrazów w opanowanie świata.

\section{2.}

O ile kulturę Warburg badał pod kątem obrazów, o tyle same wizerunki analizował w perspektywie cierpienia ${ }^{16}$. Wyrastające z gwałtownych i bolesnych wstrząsów pierwotnego człowieka, wizerunki stanowią residuum ludzkich zmagań o przetrwanie. Rys ten widać wyraźnie we wszechobecnych obrazach walki: scenach ujarzmiania potworów, smoków, bestii czy demonów, przedstawieniach dekapitacji Meduzy i innych figur grozy i chaosu. Jednak wizualnym wyrazem zmagań o przetrwanie w równiej mierze są, zdaniem Warburga, wizerunki nieprzedstawiające bezpośrednio żadnej przemocy, jak na przykład grecki obraz wszechświata jako kosmosu. Wyobrażenie harmonijnego ładu uniwersum nie powstało wyłącznie wskutek uważnej obserwacji czy chłodnej kalkulacji ruchów ciał niebieskich, ale stanowiło efekt gigantycznej duchowej konfrontacji z grozą nieba. W jej wyniku niebo, źródło odwiecznego lęku, zostało przeobrażone w swoje przeciwieństwo wyobrażenie nieba jako kosmosu mającego w tradycji greckiej walor niedoścignionego paradygmatu ładu i piękna. Takie przeobrażenie Warburg nazywał „energetyczną inwersją sensu”, rozumiejąc przez to dialektyczny proces, w obrębie którego wszelki porządek, piękno i racjonalność są efektem zderzenia z grozą i chaosem. W tej „dialektyce potworności” kontrolę nad okolicznościami zewnętrznymi i samym sobą uzyskujemy przez negowanie „monstrum” czy - jak powiada Warburg - kroczenie „per monstra ad

16 Do interpretatorów Warburga uwrażliwionych na ten aspekt jego poszukiwań należą między innymi: G. Didi-Huberman, op. cit.; Ch. Schoell-Glass, Aby Warburg and Anti-Semitism, Detroit 2008; C. Cieri Via, Menschenopfer, „Images Re-vues" 2013, no 4, https://journals.openedition.org/imagesrevues/2991 [dostęp: 22.12.2018]; eadem, „Griff nach dem Kopf”. Vincitori e vinti. La sopravvivenza di un topos antico nell'età Moderna, [w:] La Storia e le Immagini della Storia: Prospettive, metodi, ricerche, ed. M. Provasi, C. Vicentini, Roma 2015, s. 15-36. 
sphaeram"17. Rozum był tu pojmowany negatywnie - jako pokonywanie irracjonalności. Praca kultury oznaczała mozolne odsuwanie „tego, co potworne"18 - powolny ten proces okupiony był każdorazowo ogromnym wysiłkiem i cierpieniem, toteż droga do racjonalności była „zawsze dla mieszkańców ziemi drogą krzyżową"19.

Cierpienie było dla Warburga pierwotnym źródłem obrazów, a wizerunki stanowily formę jego ekspresji. Trwające nieprzerwanie od początków ludzkości zmagania o przetrwanie, orientację i kontrolę manifestowały się artystycznie w stylu, gestach i pozach. Fakt ten najlepiej bodaj uchwyciła znana kategoria Warburgiańskiej refleksji nad obrazami - koncepcja „formuł patosu". Pathosformeln to wzorce obrazowej ekspresji stanów emocjonalnych człowieka ${ }^{20}$. Hamburski uczony rozumiał przez nie pozy przyjmowane przez ludzkie ciało w stanach najintensywniejszego wzburzenia emocjonalnego. Utrwaliły się one w pewne kanony, które - wywodząc się ze szczególnie gwałtownych i bolesnych doświadczeń - najgłębiej wryły się w ludzką pamięć'1 . Formuły patosu to zatem „ślady pamięciowe” (engramy) przeżytych traum, które trwają w pamięci społecznej ${ }^{22}$. W sprzyjających okolicznościach uaktywniają się i powracają w ekspresjach artystycznych. Historia

${ }_{17}$ Zob. A. Warburg, Die Einwirkung der Sphaera barbarica..., op. cit., s. 89.

18 „Kampf mit dem Monstrum als Keimzelle der logischen Konstruktion”; cyt. za: E. Gombrich, op. cit., s. 251.

19 „Der Weg zum Logos ist für alle Erdenbewohner ein Passionsweg”; cyt. za: R. Kany, Mnemosyne als Programm..., op. cit., s. 160. W swym wspomnieniu o Warburgu z 1929 roku Ernst Cassirer zauważył, że wszystkie formuły patosu, które badał Warburg, „są, by tak rzec, jedynie różnymi stacjami wielkiej drogi krzyżowej ludzkości” („Sie alle sind gleichsam nur verschiedene Stadien des einen grossen Passionsweges der Menschheit"). E. Cassirer, Worte zur Beisetzung von Professor Dr. Aby M. Warburg, [w:] Mnemosyne. Beiträge zum 50. Todstag von Aby M. Warburg, hrsg. S. Füssel, Göttingen 1979, s. 18 (tłum. własne).

20 Formuły patosu Warburg ujmuje również w kategoriach języka gestów, którym posługiwał się człowiek dla wyrażenia stanów emocjonalnych. Są one zatem „stopniem najwyższym” czy superlativem tego języka wyrazowego. Zob. A. Warburg, Wprowadzenie, [w:] Atlas obrazów Mnemosyne, op. cit., s. 4.

${ }^{21}$ Ibidem.

${ }^{22}$ Zauważmy, że Susan Sontag odrzuca istnienie pamięci społecznej: „Ściśle rzecz biorąc, nie ma czegoś takiego jak pamięć zbiorowa - należy ona do tej samej 


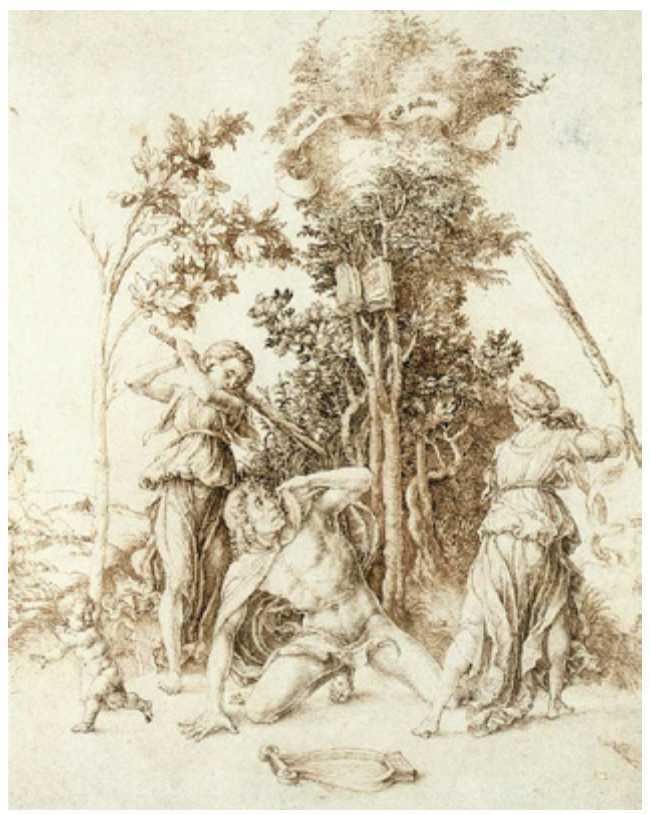

Il. 1. Albrecht Dürer, Śmierć Orfeusza, 1494 r., rysunek, Hamburger Kunsthalle symbolizacji obrazowej jawiła się Warburgowi jako społeczna mneme - skarbnica cierpień i urazów, z której czerpią artyści. Zadanie warburgiańskiego kulturoznawstwa polegało między innymi na tym, aby ów repertuar formuł patosu sklasyfikować, a i w ten sposób ów „skarb cierpień ludzkości uczynić własnością człowieka"23.

Kategorię Pathosformeln Warburg wprowadził po raz pierwszy w 1905 roku, w wykładzie pod tytułem Dürer a antyk w Italii ${ }^{24}$, ilustrując ją jego ryciną Śmierć Orfeusza (il. 1). Według legend mityczny poeta został rozszarpany przez rozszalałe Menady. U Dürera Orfeusz otoczony jest przez dwie kobiety, które w zapamiętaniu wymierzają mu ciosy. Klęcząc na ziemi, zasłania się ręką - i właśnie ów gest obronny był bezpośrednim przedmiotem namysłu hamburskiego badacza. W swym wykładzie Warburg dowodził, że gest ten Dürer zapożyczył od włoskiego artysty doby renesansu, Andrei Mantegni. Ze

rodziny fałszywych pojęć, co wina zbiorowa [...]. Wszelka pamięć jest jednostkowa, niepowtarzalna - umiera wraz z człowiekiem”. S. Sontag, op. cit., s. 103.

${ }_{23}$ Notatki do wykładu wygłoszonego w Hamburgu 10 kwietnia 1928 roku; cyt. za: U. Fleckner, "Le trésor de souffrance de l'humanité devient un bien humain”. Sarkis, Warburg et la mémoire sociale de l'art, [w:] idem, Sarkis, Das Licht des Blitzes Der Lärm des Donners, Wien 1995, s. 42 oraz 45 przyp. 9. Zob. też: M. Warnke, Der Leidschatz der Menschheit wird humaner Besitz, [w:] Die Menschenrechte des Auges. Über Aby Warburg, hrsg. W. Hofmann, Frankfurt am Main 1980, s. 113-186.

24 Streszczenie wykładu opublikowane jako: A. Warburg, Dürer a antyk w Italii, [w:] idem, Narodziny Wenus..., op. cit., s. 154. 
swej strony Mantegna naśladował wzorce antyczne, bowiem identyczny gest ręki często spotyka się na starożytnych przedstawieniach tej sceny (il. 2). Skupiając się na znaczącym szczególe - geście ręki - Warburg odsłonił trwanie pewnej formuły patosu, a dokładnie „wizualnego toposu”, czyli łańcucha tradycji przedstawieniowej ciągnącej się od starożyt-

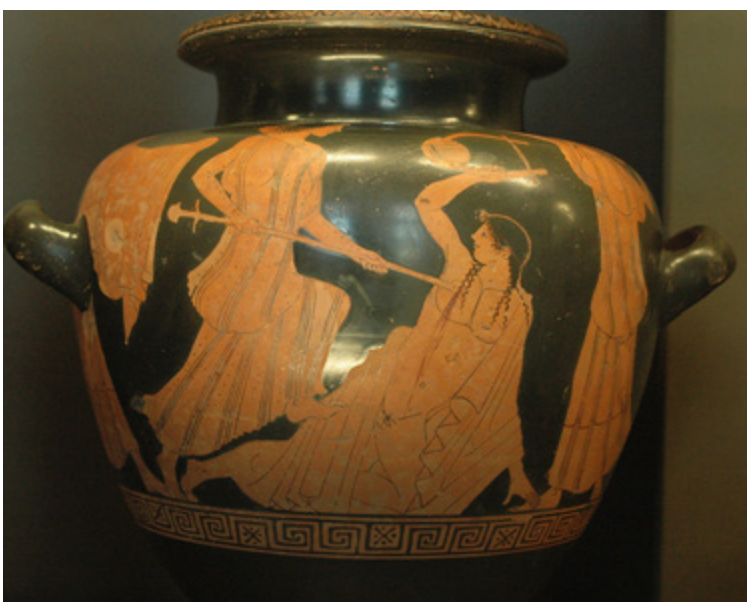

Il. 2. Śmierć Orfeusza, grecka waza z ok. 470 r. p.n.e., Luwr, Paryż ności po odrodzenie.

Jednocześnie pokazał, że owa formuła patosu - pamięć gestu ręki Orfeusza stanowi ślad ludzkiej walki o przetrwanie, będąc związana z krwawym doświadczeniem z zamierzchłej przeszłości - przeżyciem zbiorowego linczu.

\section{3.}

Do najważniejszych formuł patosu Warburg zaliczył patos zwycięzcy. Warto w tym miejscu wspomnieć o nim nieco szerzej, gdyż bezpośrednio odnosi się on do podjętego przez Susan Sontag zagadnienia „wojny jako obrazu”. Refleksja na ten temat powracała wielokrotnie w notatkach, wykładach oraz wystawach organizowanych przez Warburga. Pierwszą wzmiankę na ten temat odnajdujemy już w notce sporządzonej 16 listopada 1898 roku, ogłoszonej w zbiorze Fragmente zur Ausdruckskunde ${ }^{25}$. Wiele uwagi patosowi zwycięzcy Warburg poświęcił w cyklu prelekcji Einführung in die Kultur der italienischen Frührenaissance wygłoszonych w lutym i marcu 1909 roku

25 A. Warburg, Fragmente zur Ausdruckskunde, hrsg. U. Pfisterer, H.Ch. Hönes, Berlin 2015, s. 180. 
w Hamburgu ${ }^{26}$. Jest on także przewodnim tematem wykładu Der Eintritt des antikisierenden Idealstils in die Malerei der Frührenaissance wygłoszonego w kwietniu 1914 roku w Kunsthistorisches Institut we Florencji ${ }^{27}$. Wiele lat później uczony powrócił do tej kwestii w wystawie Urworte leidenschaftlicher Gebärdensprache zorganizowanej w Kulturwissenschaftliche Bibliothek Warburg w Hamburgu (29.01-12.02.1927) ${ }^{28}$ oraz w ramach wykładu Römische Antike in der Werkstatt des Domenico Ghirlandaio wygłoszonego w Bibliotece Hertziana w Rzymie 19 stycznia 1929 roku, a także w towarzyszącej wykładowi wystawie (19-31.01.1929) ${ }^{29}$. Wreszcie patos zwycięzcy zajmuje naczelne miejsce w ostatnim, nieukończonym dziele autora Bilderatlas: Mnemosyne $e^{30}$.

W wykładzie Wniknięcie stylu antykizującego jako ideału stylistycznego do malarstwa wczesnorenesansowego niemiecki uczony postawił centralne dla swych poszukiwań pytanie o źródła zmiany stylistycznej, jaka dokonała się w sztuce włoskiej w latach 1440-1490, kierując uwagę na fakt, że podstawowym modelem nowego, antykizującego stylu artystów renesansowych były militarystyczne formy sztuki rzymskiej.

Dobrze wiadomo, że w Rzymie istniał prawdziwy kult zwycięstwa, wynikający stąd, że militarne pokonanie wroga miało konstytutywne znaczenie

26 A. Warburg, Il primo Rinascimento italiano. Sette conferenze inedite, ed. G. Targia, Torino 2013.

27 A. Warburg, Der Eintritt des antikisierenden Idealstils in die Malerei der Frührenaissance, [w:] idem, Werke in einem Band, hrsg. M. Treml, Berlin 2010, s. 281-310.

28 Zob. A. Warburg, Urworte leidenschaftlicher Gebärdensprache (tablica: Sieg), [w:] idem, Bilderreihen und Ausstellungen, hrsg. U. Fleckner, I. Woldt, Berlin 2012, s. 91.

${ }^{29}$ Zob. A. Warburg, Römische Antike in der Werkstatt des Domenico Ghirlandaio, [w:] idem, Bilderreihen und Ausstellungen, op. cit., s. 313 i 349 (tablice 1 i 16). Zob. także: idem, Die römische Antike in der Werkstatt Ghirlandaios, Traccia della conferenza alla Biblioteca Hertziana di Roma (19 gennaio 1929), „La Rivista di Engramma" 2014, nr 19; http://www.engramma.it/eOS/index.php?id_articolo=1624 [dostęp: 22.12.18].

30 Zob. A. Warburg, Atlas obrazów Mnemosyne, op. cit., s. 31, 85 i 87 (tablice 7, 44 i 45). Zob. także: C. Cieri Via, Il trionfo antico fra pathos ed ethos, [w:] Trionfi romani, ed. E. La Rocca, Milano 2008, s. 10-18. 
polityczne. Cesarz był przede wszystkim triumfującym wodzem - victor i triumfator. Jego władzę legitymizowała skuteczność na polu walki, którą traktowano jako nieomylny znak wyjątkowej przychylności bogów ${ }^{31}$. Było to szczególnie ważne w epoce pryncypatu, gdy cesarza wybierało wojsko. Aby jednak zwycięstwo na polu bitwy przełożyło się na

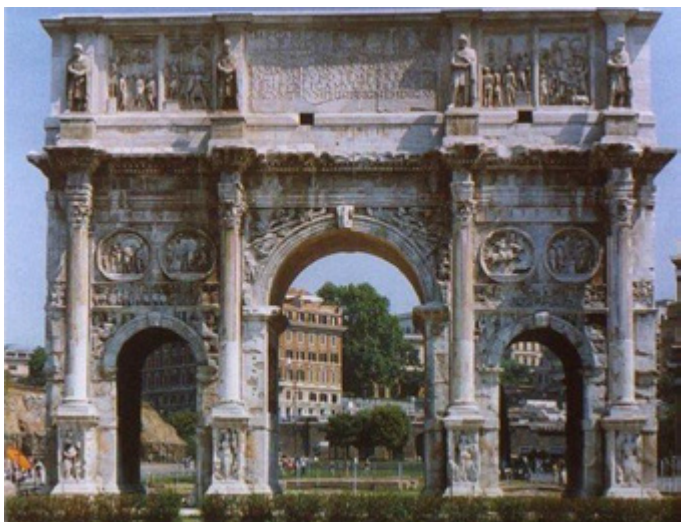

Il. 3. Łuk Konstantyna, Rzym 312-315 r. władzę polityczną, musiało ono zostać obwieszczone i „wizualnie utrwalone”32. Celowi temu służyły rozbudowane formy ekspresji: rytualne inscenizacje (ceremonia triumfu), budowle architektoniczne (łuki triumfalne, kolumny, tropaiony), pomniki zwycięskich wodzów, a wreszcie bogaty repertuar znaków zwycięstwa.

W wykładzie z 1914 roku Warburg zwrócił uwagę na wczesnorenesansową popularność najbardziej spektakularnego architektonicznego emblematu podboju militarnego, jakim były łuki triumfalne. W szczególności podkreślał popularność Łuku Konstantyna, który we wczesnym renesansie uważany był za naczelny symbol rzymskiej starożytności (il. 3). Autor zawęził swoje poszukiwania do obrazu wojny na dwudziestometrowym fryzie

${ }^{31}$ Na temat rzymskiej „teologii zwycięstwa” zob. m.in.: J. Gagé, La théologie de la victoire impériale, „Revue Historique” 1933, no 1, s. 1-43; R. Fears, The Theology of Victory at Rome: Approaches and Problem, [w:] Aufstieg und Niedergang der römischen Welt (II.17.2), hrsg. W. Haase, H. Temporini, Berlin 1981, s. 736-826.

32 Zob. T. Hölscher, The Transformation of Victory into Power: From Event to Structure, [w:] Representations of War in Ancient Rome, ed. S. Dillon, K.E. Welch, Cambridge 2006, s. 27-48; K.R. Krierer, Sieg und Niederlage: Untersuchungen physiognomischer und mimischer Phänomene in Kampfdarstellungen der römischen Plastik, Wien 1995. 


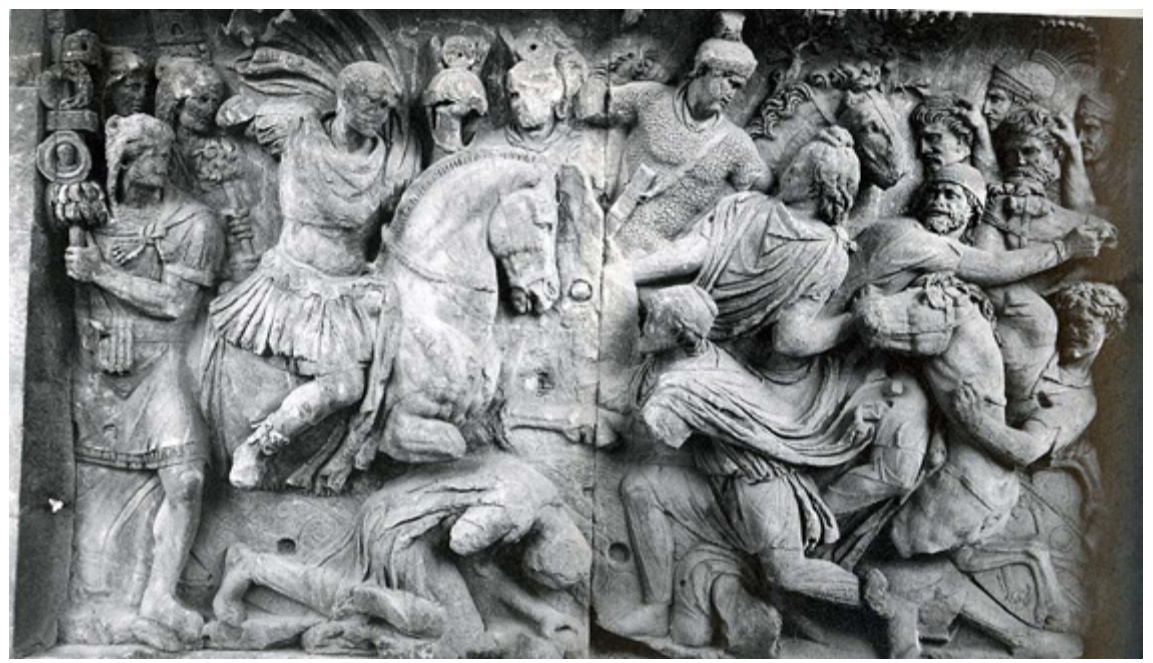

Il. 4. Trajan walczący z Dakami, relief $z$ wielkiego fryzu Trajana, Łuk Konstantyna, Rzym 312-315 $r$.

znajdującym się w centralnej zatoce Łuku Konstantyna ${ }^{33}$. Przeniesiony ze starszego obiektu, wyobraża on zwycięstwo Trajana nad Dakami, streszczając szereg epizodów bitewnych w jedną kompozycyjną całość. Główna scena fryzu ukazuje cesarza jako heroicznego wojownika, pogromcę Daków. Jego bezpośrednie zaangażowanie - władca walczy osobiście na pierwszej linii frontu - sprawia, że wrogowie w popłochu rzucają się do ucieczki (il. 4). W scenie tej naczelnym elementem jest konna szarża cesarza - motyw tratowania powalonego wroga przez jeźdźca - a także klęcząca postać błagającego o litość wodza Daków.

W repertuarze rzymskich znaków zwycięstwa deptanie wroga zajmowało miejsce szczególne. Sukces militarny z reguły obrazowano scenami miażdżenia, tratowania lub deptania. Przedstawiano wrogów deptanych stopą triumfatora ${ }^{34}$ lub tratowanych końskimi kopytami. Kompozycja kon-

${ }_{33}$ Zob. A.M. Leander-Touati, The Great Trajanic Frieze. The Study of a Monument and of the Mechanisms of Message Transmission in Roman Art, Stockholm 1987.

${ }_{34} \mathrm{Na}$ temat calcatio colli zob. J. Babelon, Le thème iconographique de la violence, [w:] Studies presented to David Moore Robinson, vol. II, ed. G.E. Mylonas, Saint Louis 1951, s. 278-288. 
trastująca stającego dęba wierzchowca i powalonego lub martwego wroga czy też jeźdźca na wspinającym się koniu i rozciągniętą na ziemi postać ma swój pierwowzór w sztuce greckiej. Pojawiała się często zarówno w okresie klasycznym, jak i hellenistycznym. Jednym z najbardziej znanych jej przykładów jest stela nagrobna Deksileosa w Atenach (il. 5) ${ }^{35}$. W porównaniu greckich i rzymskich ujęć tego motywu uderza odmienność reprezentacji wroga. Na steli nagrobnej powalona postać ukazana została jako równorzędny przeciwnik jeźdźca ${ }^{36}$, podczas gdy na fryzie Trajana między cesarzem na koniu a skulonym Dakiem zachodzi wyraźna dysproporcja, komunikująca militarną i moralną wyższość postaci jeźdźca. Sugerowała ona, że rzymskie zwycięstwo nie było odniesione nad godnym rywalem, lecz nad gorszym, tchórzliwym „barbarzyńcą”, którego łatwo zmusić do uległości. Uległość tę wyobraża postać Daka rzucającego się przed cesarzem na kolana ${ }^{37}$.

35 Warburg przywołał stelę Deksileosa we wspomnianym już wykładzie Dürer a antyk $w$ Italii. Zob. M.A. Hurttig, Warburg Vortrag „Dürer und die italienische Antike", [w:] idem, Die entfesselte Antike. Aby Warburg und die Geburt der Pathosformel, Hamburg 2011, s. 23.

36 Warto przywołać opis steli Deksileosa, który dał E.H. Kantorowicz w jednym ze swych niepublikowanych wykładów: „Patrząc na grecką reprezentację zwycięstwa, np. na stelę nagrobną Deksileosa z początków IV wieku na ateńskim cmentarzu Kerameikos, widzimy nie tylko chwałę zwycięzcy, ale także ludzką tragedię pokonanego. Za chwilę cios pozbawi życia pobitego wojownika, który umrze z przerażającym widokiem konia wspinającego się nad jego głową. Zostanie stratowany końskimi kopytami i przeszyty lancą jeźdźca. Scena ta bezpośrednio nas dotyka, gdyż nas po ludzku wzrusza. Nie ma w niej czynnika moralnego, żadnej nienawiści czy miłości zarówno wobec zwycięzcy, jak i wobec pokonanego. Jednak wstrzymujemy oddech, gdyż dialektyka tej płaskorzeźby to dialektyka samego życia i śmierci. Zwycięski jeździec wydaje się sam rozumieć, że Mojra czy Los mogły równie dobrze odwrócić role i że to on mógł zostać zwyciężony i leżeć pod końskimi kopytami. Zwycięzca i zwyciężony są po ludzku równi, niczym bracia, a ich role mogą się odwrócić nawet w ostatniej chwili” (tłum. własne). E.H. Kantorowicz, Roman Coins and Christian Rites, www.archive.org/stream/ernstkantorowicz00reel01\#page/n1057/mode/lup [dostęp: 22.12.18].

37 Na temat obrazu barbarzyńców w sztuce rzymskiej zob. P. Zanker, I barbari, l'imperatore e l'arena. Immagini di violenza nell'arte romana, [w:] idem, Un'arte per 


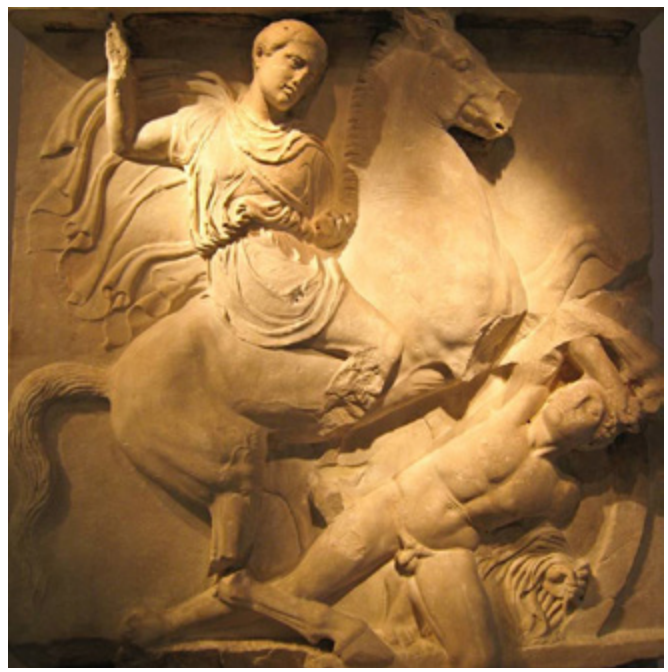

Il. 5. Stela nagrobna Deksileosa, 394-393 r. p.n.e., Narodowe Muzeum Archeologiczne w Atenach
Scena ta reprezentuje kluczową dla wizerunków zwycięstwa - i zasadniczą dla koncepcji samego Warburga dialektykę triumfatora i pokonanego ${ }^{38}$. Konstytutywnym elementem wizualnej reprezentacji triumfu jest nie tylko zwycięski jeździec na wspinającym się koniu - jest nim także powalony wróg. Obraz zwycięstwa niejako wymagał widoku ofiar - przedstawienia zabijanych przeciwników czy upokorzonych jeńców. Toteż najbardziej spektakularna wizualizacja chwały i potęgi Rzymu - pochód triumfalny -

obejmowała nie tylko zwycięskiego wodza stojącego na wozie, odzianego $\mathrm{w}$ purpurową togę, $\mathrm{z}$ wieńcem laurowym na głowie; istotowym elementem pochodu zmierzającego z Pola Marsowego na Kapitol byli również prowadzeni tuż przed triumfalnym wozem cesarza jeńcy wojenni, których później zabijano $^{39}$. Eksponowanie skutych jeńców było również stałym elementem wizerunków cesarskiej apoteozy, jak w przypadku Gemma Augustea, gdzie para jeńców siedzi na ziemi w scenie podnoszenia tropaionu. Tę dialektykę zwycięstwa najlepiej jednak oddaje inny, często przez Warburga przywoływany, fragment fryzu Trajana, w którym po prawej stronie widzimy

l'Impero: Funzione e intenzione delle immagini nel mondo romano, Milano 2002, s. 38-62.

38 Zob. A. Warburg, Fragmente zur Ausdruckskunde (356), op. cit., s. 180; M. Ghelardi, Aby Warburg. La lotta per lo stile, Torino 2012, s. 340.

39 Zob. K. Balbuza, Triumfator. Triumf $i$ ideologia zwycięstwa $w$ starożytnym Rzymie epoki cesarstwa, Poznań 2005. Pochód triumfalny można rozumieć zatem jako rozbudowany rytuał ofiarny. Zagadnienie ofiar z ludzi należało do centralnych tematów refleksji Warburga. Zob. C. Cieri Via, Menschenopfer..., op. cit. 
cesarza (Trajana) koronowanego przez skrzydlatą Wiktorię, natomiast po lewej stronie bogini zwycięstwa galopujący jeździec tratuje leżącego wroga (il. 6). Innymi słowy, wyniesienie symbolizowane przez koronę rozumie się tu jako nagrodę za powalenie i przygniatanie wroga do ziemi. Patos cesarskiego triumfu i zadawanie cierpienia ofia-

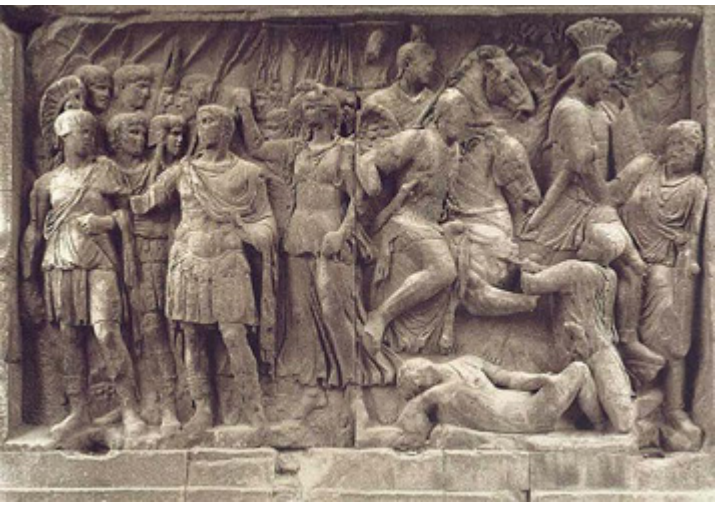

Il. 6. Trajan koronowany przez Wiktorię, relief z wielkiego fryzu Trajana, Łuk Konstantyna, Rzym 312-315 r. rom to dwie strony tego samego procesu.

Choć cesarski język obrazowy często adaptowano na potrzeby ikonografii chrześcijańskiej ${ }^{40}$, to wizerunek jeźdźca tratującego powalonego wroga zniknął ze średniowiecznego imaginarium. Sama postać konna utraciła wówczas aurę heroizmu, którą cieszyła się w czasach rzymskiej starożytności ${ }^{41}$, natomiast zastanym rzymskim formułom patosu zwycięstwa, w tym scenom tratowania, chrześcijaństwo nadało odrębny sens. Warburg przypomniał, że średniowieczni odbiorcy Łuku Konstantyna na scenę błagającego o litość, klęczącego Daka mogli patrzeć przez pryzmat popularnej w tamtym czasie legendy o Trajanie. Znana jeszcze Dantemu (Czyściec X, 73-94), opowiadała o wyruszającym na kampanię wojenną cesarzu, który został zatrzymany przez matkę syna zadeptanego kopytami rzymskiej kawalerii ${ }^{42}$.

${ }^{40}$ Jak na przykład w przypadku motywu deptania karku, który w średniowieczu nie znika z chrześcijańskiej tradycji obrazowej. Zob. E.H. Kantorowicz, Roman Coins..., op. cit.; J. Sprutta, Calcatio jako triumf Boga nad złem: szkic zagadnienia, „Studia Gnesnensia” 2016, nr 30, s. 289-299.

${ }_{41}$ Zob. M. Barasch, Roman Imperial Images, [w:] idem, The Language of Art: Studies in Interpretation, New York - London 1997, s. 239.

${ }^{42}$ We Wprowadzeniu do Atlasu obrazów Mnemosyne (op. cit., s. 5) Warburg ujmuje to następująco: „Sam Kościół przez podanie, żywe jeszcze u Dantego, 
Kobieta poprosiła cesarza o wymierzenie zabójcy sprawiedliwości. Trajan początkowo obiecywał zająć się sprawą po powrocie z wyprawy, jednak wskutek błagań matki niezwłocznie kazał ukarać winnego. Legenda ta wpisywała się w średniowieczny obraz Trajana jako wzoru cnotliwego władcy ${ }^{43}$. Średniowiecznemu obserwatorowi łuku triumfalnego pozwalała widzieć w jeźdźcu bezwzględnie rozjeżdżającym barbarzyńcę - cesarza Konstantyna w roli strażnika sprawiedliwości. W wyniku energetycznej inwersji sensu emblemat rzymskiego zwycięstwa militarnego stał się obrazem cesarskiego „miłosierdzia”44.

Renesansowe odnowienie antyku w znacznej mierze oznaczało powrót rzymskiego triumfalizmu. Jak zauważył już Jakub Burckhardt, usiłowano wówczas wskrzesić rzymskie triumfy: „wspaniałe pochody karnawałowe, urządzane za Pawła II, Sykstusa IV i Aleksandra VI, przedstawiają najulubieńszy wówczas obraz fantastyczny: tryumf rzymskich imperatorów. Gdziekolwiek chodziło o wyrażenie patosu, stale pojawiał się on w tej

przeistoczył pełne chwały samowładztwo z reliefu Trajana w postawę chrześcijańską. W słynnej opowieści o litości cesarza dla wdowy błagającej o sprawiedliwość podjęto bodaj najsubtelniejszą próbę przemienienia - przez energetycznie odwrócone nadanie sensu - imperatorskiego patosu w chrześcijańską litościwość; tak cesarz galopujący na wewnętrznej części reliefu, tratujący barbarzyńcę - staje się rzecznikiem sprawiedliwości, który rozkazał swojemu orszakowi, by się zatrzymał, ponieważ pod kopyta rzymskich jeźdźców dostało się dziecko wdowy”. Zob. także: ibidem, s. 99 (tablica 52): „Sprawiedliwość Trajana = inwersja energetyczna tratowania kopytami. Etyczne odwrócenie patosu zwycięzcy”. Zob. też: A. Warburg, Il primo Rinascimento italiano, op. cit., s. 15-26. Na temat chrześcijańskiego mitu Trajana zob. m.in.: J. Seznec, Diderot and „The Justice of Trajan”, „Journal of the Warburg and Courtauld Institutes" 1957, no 1-2, s. 106-111.

${ }^{43}$ Według popularnej legendy, zachowanej w żywocie Grzegorza Wielkiego, papież, przechodząc w Rzymie przez forum Trajana, wspomniał wyjątkową sprawiedliwość tego cesarza. Na myśl o pośmiertnym losie pogańskiego władcy, będącego wzorem cnót, wzruszył się na tyle, że wstawił się za niego modlitwą do Boga. Została ona wysłuchana i cesarzowi oszczędzone zostało wieczne potępienie w piekle. Zob. J. Mikołajewski, Rzymska komedia, Warszawa 2011, s. 366-367.

${ }^{44}$ A. Warburg, Wprowadzenie, [w:] idem, Atlas obrazów Mnemosyne, op. cit., s. 4 . 
formie"45. Mianem trionfo określano wówczas uliczną procesję, która narodziła się $\mathrm{w}$ renesansowych Włoszech, a następnie rozpowszechniła się w całej Europie. Takie inscenizowane nawiązanie do rzymskich pochodów zwycięskich wodzów miało swój pierwowzór w literaturze. Wywodziło się

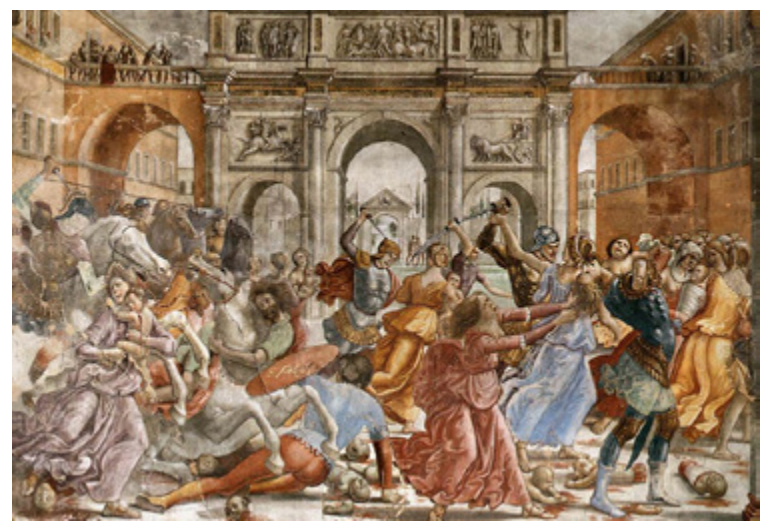

Il. 7. Domenico Ghirlandaio, Rzeź niewiniątek, fresk, 1485-1490, kaplica Tornabuonich, Santa Maria Novella, Florencja z najpopularniejszego dzieła literackiego tamtego czasu - Triumfów Petrarki ${ }^{46}$. Triumfy przeniknęły również do sztuk plastycznych, gdzie sceny alegorycznych, mitologicznych czy historycznych pochodów stały się jednym z najczęstszych motywów malarskich ${ }^{47}$. Wierszowane, malowane oraz inscenizowane triumfy oddziaływały wzajemnie na siebie. Jednak Warburg powrót rzymskiego triumfalizmu rejestruje precyzyjniejszym „parametrem”, a mianowicie - „recepcją” Łuku Konstantyna i jego rzeźb w malarstwie odrodzeniowym. Renesansowi artyści uznali ten łuk za emblemat antyku i wykorzystywali go jako tło dla

${ }^{45}$ J. Burckhardt, Kultura odrodzenia we Włoszech, tłum. M. Kreczkowska, Warszawa 1965, s. 101. Szerzej zob. M. Zaho, Imago Triumphalis: The Function and Significance of Triumphal Imagery for Italian Renaissance, New York 2004.

${ }_{46}$ Chcąc ustanowić poetę jako nowego suwerena stojącego na równi z najwyższą władzą świecką (cesarzem) i duchową (papieżem), Petrarka wykorzystał konotacje związane w antycznym triumfem. Za swe poetyckie zasługi 8 kwietnia 1341 roku otrzymał z rąk rzymskiego senatora na Kapitolu koronę - najwyższe insygnium władzy monarszej. Zob. E.H. Kantorowicz, The Sovereignty of the Artist: A Note on Legal Maxims and Renaissance Theories of Art, [w:] idem, Selected Studies, New York 1965, s. 353-365.

$47 \mathrm{Na}$ temat wizerunków triumfalnych we wczesnym renesansie zob. m.in. G. Carandente, I Trionfi nel primo Rinascimento, Moncalieri 1963. 


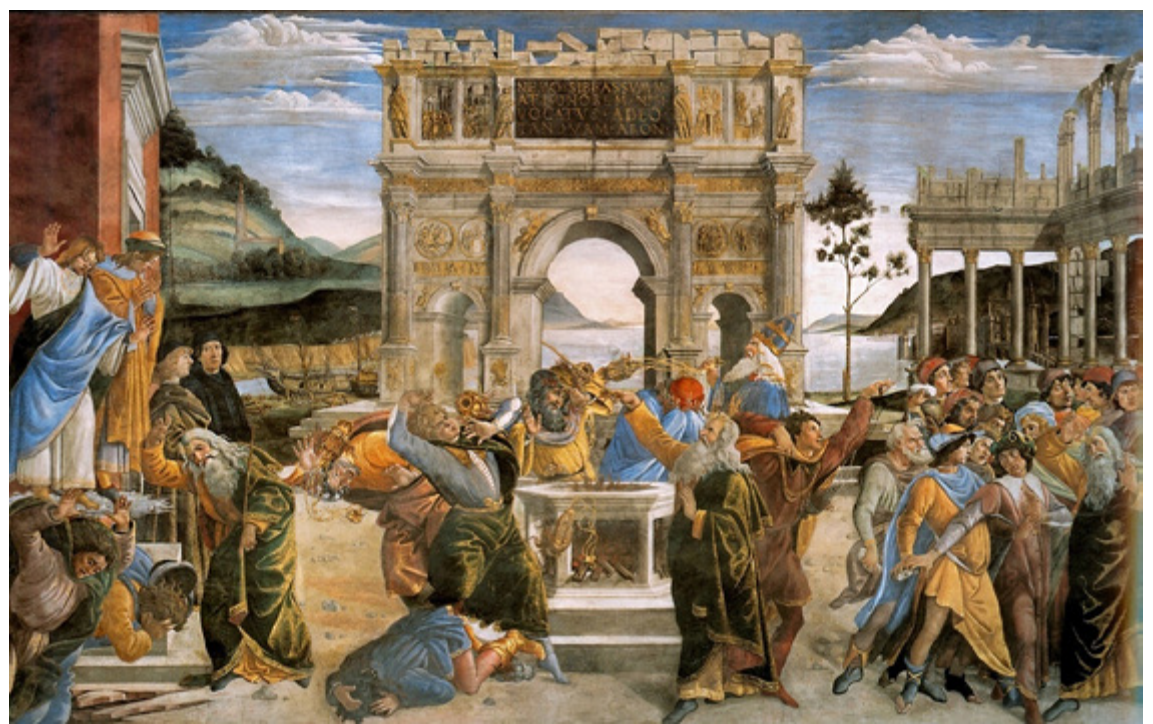

Il. 8. Sandro Botticelli, Bunt Koracha, fresk, 1481-1482, Kaplica Sykstyńska, Watykan

przedstawień scen biblijnych. Domenico Ghirlandaio na fresku w kościele Santa Maria Novella we Florencji przeniósł do Rzymu ewangeliczną historię „rzezi niewiniątek” (il. 7). Sandro Botticelli w Kaplicy Sykstyńskiej na tle oddanego ze szczegółami Łuku Konstantyna umieścił epizod ze Starego Testamentu - Ukaranie buntowników: Koracha, Datana i Abirama (il. 8). $\mathrm{Na}$ fresku Zachariasz $w$ świątyni w kaplicy Tornabuonich kościoła Santa Maria Novella we Florencji Domenico Ghirlandaio namalował grisaille reprodukujący scenę z fryzu Trajana ${ }^{48}$ (il. 9).

Najbardziej prominentnym świadectwem oddziaływania Łuku Konstantyna jako siły kształtującej antykizujący styl renesansowy są jednak stanze Rafaela, zwłaszcza Sala Konstantyna, zaprojektowana na zlecenie papieża Juliusza II, w oczach współczesnych malarzowi uchodząca za najwspanialszy jego dar dla potomności ${ }^{49}$. Zdobi ją między innymi fresk

48 Zob. A. Warburg, Atlas obrazów Mnemosyne, op. cit., s. 85 (tablica 44: Grisaille jako pierwszy stopień recepcji patosu zwycięzcy).

49 Ph.P. Fehl, Raphael as a Historian: Poetry and Historical Accuracy in the Sala di Costantino, „Artibus et Historiae” 1993, no 28, s. 9. 


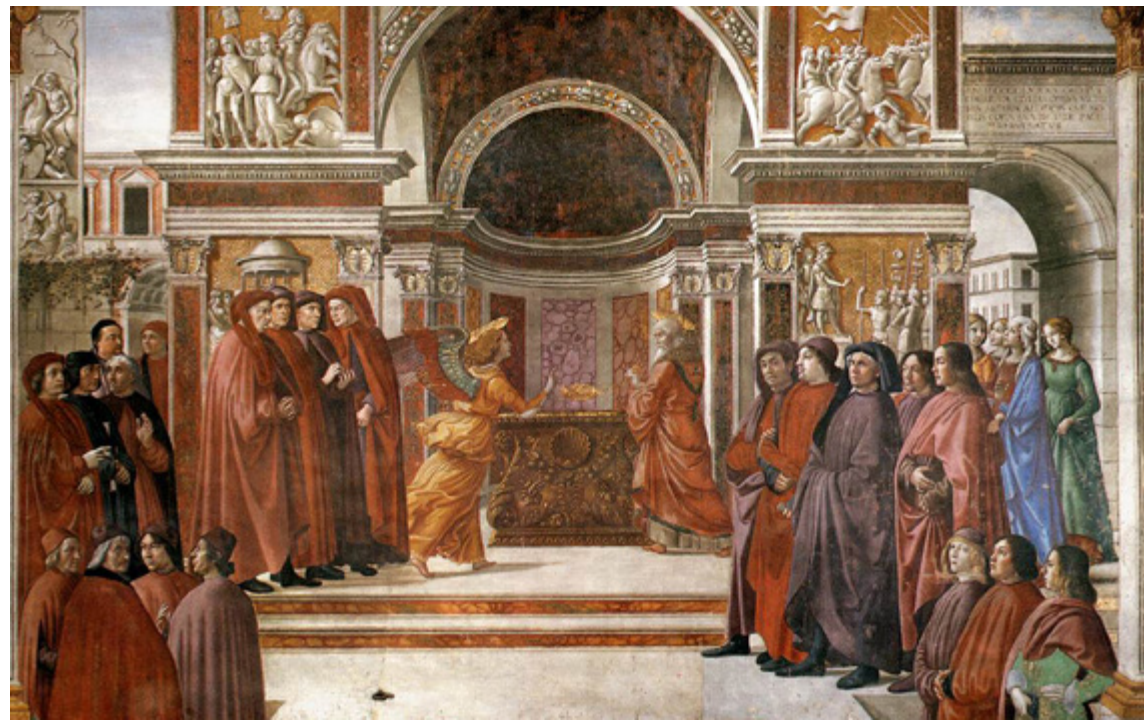

Il. 9. Domenico Ghrilandaio, Zachariasz w świątyni, fresk, 1485-1490, kaplica Tornabuonich, Santa Maria Novella, Florencja

przedstawiający bitwę przy moście Mulwijskim (il. 10). Wykonany na podstawie rysunków Rafaela przez jego ucznia, Giulia Romano, ukazuje przełomowe zwycięstwo cesarza, które otworzyło drogę do jego konwersji na chrześcijaństwo.

Rozpoznajemy tu elementy typowe dla rzymskiego patosu zwycięstwa: triumfujący wódz jadący na czele swej armii; wiktoria jest pochodną jego osobistego zaangażowania w walkę; wspinający się koń tratuje kopytami pokonanych wrogów. Nie ma wątpliwości, że kluczowe dla fresku okazały motywy zaczerpnięte $\mathrm{z}$ reliefów łuku upamiętniającego zwycięstwo odniesione przez Konstantyna nad Maksencjuszem. W wykładzie z 1914 roku Warburg podkreślał, że „chociaż oba dzieła dzieli od siebie 1200 lat, to należy rozpatrywać je łącznie, gdyż [...] fresk szkoły Rafaela zawdzięcza swój innowacyjny styl, nacechowany heroicznym dynamizmem, bezpośrednio rzeźbom Łuku Konstantyna” ${ }^{50}$. Z rzeźb tych emanował „imperatorski patos”

50 A. Warburg, Der Eintritt des antikisierenden Idealstils..., op. cit., s. 281. 


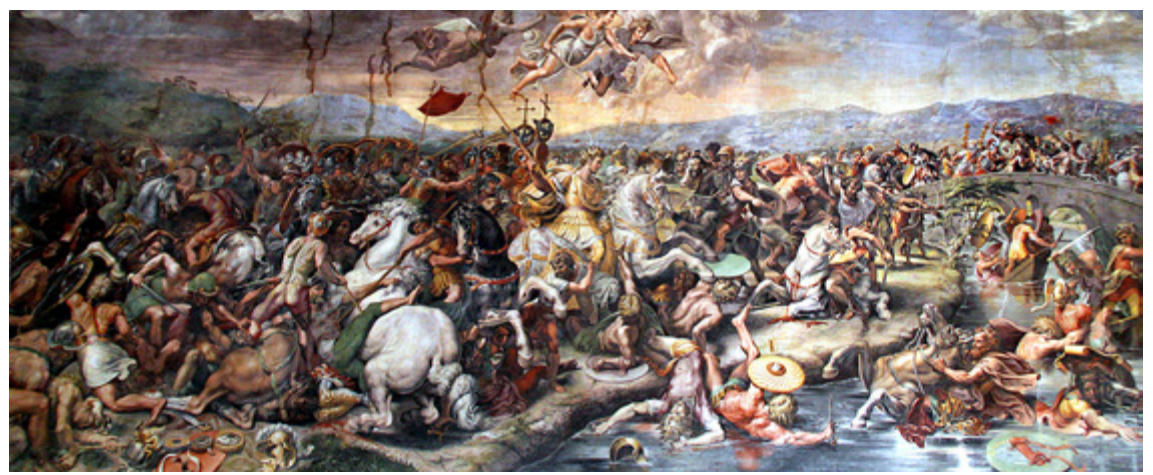

Il. 10. Guilio Romano, Bitwa Konstantyna, 1520-1524, fresk, Sala Konstantyna, Watykan

i „odurzająca elokwencja języka gestów” ${ }^{51}$, której poddali się Rafael i Giulio Romano. Sprawiły one, że umiarkowana ekspresja, charakterystyczna dla wczesnego renesansu, ustąpiła miejsca wybujałej retorycznej afektacji, antycypującej styl barokowy. Aby to pokazać, Warburg zestawił watykańską reprezentację bitwy przy moście Mulwijskim z wcześniejszym ujęciem tego samego tematu, ukazanym w Arezzo przez Piera della Francescę (il. 11) ${ }^{52}$. Nie ma wątpliwości, że również ten artysta znał rzeźby fryzu Trajana. Także on ukazał cesarza ruszającego do boju na czele swej armii. W tym ujęciu

${ }^{51}$ A. Warburg, Wprowadzenie, [w:] idem, Atlas obrazów Mnemosyne, op. cit., s. 7.

52 Warburg wielokrotnie zestawiał oba ujęcia bitwy, zob. np. A. Warburg, Il primo rinascimento italiano, op. cit., s. 91; idem, Atlas obrazów Mnemosyne, op. cit., s. 55 (tablica 30: Ustanowienie dystansu). Fresk Bitwa Konstantyna Piera della Franceski z kaplicy św. Franciszka w Arezzo uległ częściowemu uszkodzeniu. Warburg posługiwał się kopią wykonaną przez niemieckiego artystę Johanna Antona Ramboux pod koniec lat 30. XIX wieku, to jest w czasie, gdy fresk był w nieco lepszym stanie niż obecnie. Zob. A. Warburg, Piero della Francescas Constantinschlacht in der Aquarellkopie des Johann Anton Ramboux, [w:] L'Italia e l'arte straniera: atti del X Congresso Internazionale di Storia dell'Arte in Roma (1912), ed. A. Venturi, Roma 1922, s. 326-327, ilustracje: LXXIX-LXXX. Zob. też: C. Wedepohl, Aby Warburg und die Aquarellkopie des Johann Anton Ramboux nach Piero della Francescas "Konstantinsschlacht” in Arezzo, [w:] Artium conjunctio: Kulturwissenschaft und Frühneuzeitforschung; Aufsätze für Dieter Wuttke, hrsg. P. Schöner, G. Hübner, Baden-Baden 2013, s. 347-380. 


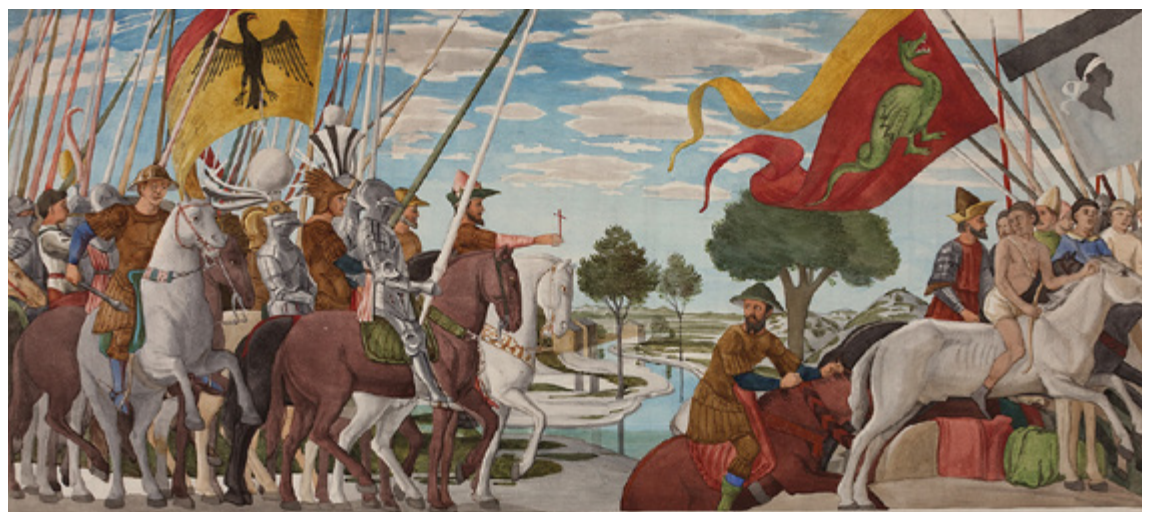

Il. 11. Johann Anton Ramboux, Bitwa Konstantyna, ok. 1838-1840, akwarela, Museum Kunstplast Düsseldorf (๑) Artothek - Bildagentur der Museen)

jednak zwycięstwo Konstantyna odniesione zostało nie tyle mocą militarnego wysiłku wodza, ile „w znaku krzyża”. Cesarz ze spokojem trzyma w dłoni niewielki krucyfiks, i to przed nim pierzchają Maksencjusz wraz z jego wojskiem. Innymi słowy, w odróżnieniu od ucznia Rafaela, Piero della Francesca nie poddał się całkowicie patosowi emanującemu $\mathrm{z}$ antycznego wzorca. Warburg ze smutkiem konstatuje, że nacechowana dystansem nieretoryczna wielkość form wyrazu oraz wyrafinowanie wizerunku z Arezzo zostały „stratowane pod kopytami dzikiego wojska, które wpada galopem na ściany Stanz pod pretekstem zwycięstwa Konstantyna"53.

Zdaniem Warburga żadnej głębokiej zmiany stylistycznej nie sposób wyjaśniać jedynie w kategoriach estetycznych. Nowy, patetyczny język gestów nie pojawił się w pracowniach malarskich wyłącznie dlatego, że wydał się ówczesnym artystom bardziej atrakcyjny ${ }^{54}$. W perspektywie antropologiczno-psychologicznej zwrot stylistyczny jest symptomem przeobrażeń dokonujących się na poziomie mentalności. W pierwszych swoich pracach Warburg z uwagą śledził pojawienie się dynamizmu wczesnorenesansowych form - zwłaszcza motywu rozwianych włosów i powiewających szat. Dostrzegał w nich zerwanie z majestatycznym bezruchem sztuki

53 A. Warburg, Wprowadzenie, [w:] idem, Atlas obrazów Mnemosyne, op. cit., s. 7.

${ }^{54}$ Zob. ibidem. 
średniowiecznej i oznakę wyzwolenia się ciała z krępujących go średniowiecznych ograniczeń. Traktował jako symbol „powiewu” nowych czasów epoki wyostrzonej świadomości własnej odrębności, obniżonego poziomu lęku przed aktywnością i wzrostu poczucia sprawstwa. Krótko mówiąc, w Odrodzeniu widział epokę emancypacji i oświecenia. Problem z dynamizmem późnorenesansowej ekspresji - z „orgią ruchu”55 oraz „jałowością biegu form" u Giulio Romano - polega na tym, że stanowił on symptom regresu. W bitewnym szale skłębiona masa ciał ulega odindywidualizowaniu. Gwałtowne ruchy zdają się świadczyć, że wahadło kultury wychyla się ku biegunowi przemocy i utraty dystansu. Pod pretekstem zwycięstwa Konstantyna na mury watykańskich komnat wdarł się styl manifestujący wiarę w siłę i militaryzm ${ }^{56}$.

\section{4.}

Znamienne jest, że temat renesansowego powrotu triumfalistycznego patosu rzymskiej sztuki Warburg podjął w kwietniu 1914 roku. Na kilka miesięcy przed wybuchem pierwszej wojny światowej chciał mówić o eskalacji przemocy dostrzeżonej w zmianie stylu malarskiego. Lata wojny hamburski uczony spędził w Niemczech, pracując nad rozprawą o wizualnej propagandzie politycznej w czasach Lutra ${ }^{57}$ oraz śledząc propagandę wizualną walczących stron toczącego się konfliktu, który dzięki rozpowszechnieniu fotografii stał się również „wojną na obrazy” ${ }^{58}$. W latach 1914-1918 Warburg

55 A. Warburg, Der Eintritt des antikisierenden Idealstils..., op. cit., s. 269.

${ }^{56}$ W stanzach Rafaela scena tratowania pojawia się również na fresku Wypędzenie Heliodora ze świątyni. M. Barasch twierdzi jednak, że w odróżnieniu od sztuki rzymskiej „w odrodzeniu stający dęba koń nie napotyka skutego, powalonego, zwyciężonego czy martwego barbarzyńcy" (tłum. własne). M. Barasch, Symbols of Authority: Roman Imperial Images in the Middle Ages, [w:] idem, The Language of Art..., op. cit., s. 239.

57 Zob. A. Warburg, Pogańsko-antyczne wróżbiarstwo w tekstach i przedstawieniach obrazowych w czasach Lutra, [w:] idem, Narodziny Wenus..., op. cit., s. 217-295. Tekst ten dotyczy manipulacji obrazami w celu zdyskredytowania misji Lutra.

58 Zob. G. Didi-Huberman, Sampling Chaos. Aby Warburg and the Photographic Atlas of the Great War, „Études Photographiques” 2011, no 27, s. 54. 
zgromadził obszerne archiwum wojenne, liczące siedemdziesiąt dwa kartony zdjęć, fotografii prasowych, map, wykresów oraz rozmaitych innych dokumentów. Wiadomo, że przez ten okres skrupulatnie przeglądał wiele niemieckich, angielskich i francuskich tytułów prasowych ${ }^{59}$. Zgodnie ze swym rozumieniem zadania kultury jako pochwycenia fobicznego odruchu i przetworzenia go w symbol, zmierzył się z monstrum wojennej grozy, przypłacając to wieloletnim załamaniem nerwowym.

W 1927 roku, trzy lata po opuszczeniu kliniki psychiatrycznej, Warburg uczynił kolejne podejście do zamknięcia w obrazie widoków ludzkiego cierpienia. Miała być to suma jego dotychczasowego dorobku, tym razem w postaci montażu obrazów - atlasu Mnemosyne. Na tablicach o wymiarach $150 \times 200 \mathrm{~cm}$, powleczonych czarną tkaniną, hamburski badacz przytwierdzał czarno-białe reprodukcje dzieł sztuki, mapy, wycinki prasowe, fotografie reklamowe etc. W chwili jego śmierci projekt liczył sześćdziesiąt trzy tablice, obejmujące blisko tysiąc obiektów. Każda z nich stanowiła swoisty fotoesej unaoczniający antyczne formuły patosu, ich przemieszczanie się w czasie i przestrzeni: powrót w epoce renesansu, a także stałą obecność w epoce współczesnej. Wyróżnioną pozycję zajmował wśród nich patos zwycięzcy, któremu wprost poświęcone zostały tablice siódma (Triumf rzymski, Łuk triumfalny, Nike, Apoteoza, Podbój) oraz czterdziesta czwarta (Patos zwycięzcy u Ghirlandaia, Grisaille jako pierwszy stopień jego recep$c j i)^{60}$. Jednak temat ten przewijał się też $\mathrm{w}$ wielu innych miejscach atlasu, toteż Maurizio Ghelardi uznał go za wyraz jego głębokiej „struktury oraz wewnętrznej logiki"61.

59 Z archiwum tego zachowała się niewielka część przechowywana w Instytucie Warburga w Londynie, dotychczas nie w pełni przebadana. Zob. G. Korff, Kasten 117. Aby Warburg und der Aberglaube im Ersten Welkrieg, Tübinger Vereinigung für Volkskunde, Tübingen 2007; oraz film Nataschy Nisic Plutôt mourir que mourir (2017).

60 A. Warburg, Atlas obrazów Mnemosyne, op. cit., s. 31, 85 i 87 (tablice 7, 44 i 45).

${ }^{61}$ M. Ghelardi, Struttura e logica intera del „Bilderatlas Mnemosyne”: il „pathos” del vincitore e lo stile trionfale romano come esempi di trasformazione dello stile, [w:] idem, Aby Warburg..., op. cit., s. 323-369. 
Atlas obrazów Mnemosyne urzeczywistniał naczelne zadanie warburgiańskiego kulturoznawstwa. Unaoczniając zakorzenione w cierpieniu formy ekspresji, czynił widzialnym „skarb cierpień ludzkości”. Poprzez montaż obrazów starał się osiągnąć to, co od zarania historii człowieka należało do podstawowych zadań wizerunków: ustanawiać dystans i przestrzeń myślową, przepracowywać zbiorowe traumy, neutralizując ich destrukcyjny potencjał.

Wprawdzie celem niniejszego szkicu nie było porównanie koncepcji Aby'ego Warburga i Susan Sontag, może na koniec warto jednak zauważyć, że pomimo wielorakich różnic obu stanowisk, spotykają się one w swej trudnej wierze w znaczenie obrazów cudzego cierpienia. Albowiem - przy całej ambiwalencji nieusuwalnie związanej z wizerunkami - należały one zawsze do podstawowych ludzkich gestów obronnych.

\section{Bibliografia}

Jean Babelon, La thème iconographique de la violence, [w:] Studies Presented to David Moore Robinson on his Seventieth Birthday, vol. II, ed. G.E. Mylonas, Washington University Press, Saint Louis 1953.

Katarzyna Balbuza, Triumfator. Triumfi ideologia zwycięstwa w starożytnym Rzymie epoki cesarstwa, Wydawnictwo Poznańskie, Poznań 2005.

Wojciech Bałus, Dlaczego Warburg?, „Przegląd Kulturoznawczy” 2010, nr 2.

Moshe Barasch, The Language of Art: Studies in Interpretation, New York University Press, New York 1997.

Jan Białostocki, Posłanie Aby M. Warburga: Historia sztuki czy historia kultury?, [w:] idem, Refleksje i syntezy, PWN, Warszawa 1987.

Agata Bielik-Robson, "Homo anxius”. Nowoczesność, czyli eksodus z lęku, „ER(R)GO. Teoria - Literatura - Kultura” 2014, nr 29.

Jakub Burckhardt, Kultura odrodzenia we Włoszech, tłum. M. Kreczkowska, PIW, Warszawa 1965.

Giovanni Carandente, I Trionfi nel primo Rinascimento, ERI, Torino 1963.

Ernst Cassirer, Worte zur Beisetzung von Professor Dr. Aby M. Warburg, [w:] Mnemosyne. Beiträge zum 50. Todstag von Aby M. Warburg, hrsg. S. Füssel, Gratia-Verlag, Göttingen 1979.

Claudia Cieri Via, „Griff nach dem Kopf”. Vincitori e vinti. La sopravvivenza di un topos antico nell'età Moderna, [w:] La Storia e le Immagini della Storia: Prospettive, metodi, ricerche, hrsg. M. Provasi, C. Vicentini, Viella, Roma 2015. 
Claudia Cieri Via, Menschenopfer, „Images Re-vues” 2013, nr 4, https://journals. openedition.org/imagesrevues/2991.

Claudia Cieri Via, Il trionfo antico fra pathos ed ethos, [w:] Trionfi romani, ed. E. La Rocca, Electa, Milano 2008.

Georges Didi-Huberman, Sampling Chaos. Aby Warburg and the Photographic Atlas of the Great War, „Études Photographiques” 2011, no 27.

Georges Didi-Huberman, Tragedia kultury: Warburg i Nietzsche, tłum. K. Jóźwiak, „Kronos” 2015, nr 3.

Rufus J. Fears, The Theology of Victory at Rome: Approaches and Problem, [w:] Aufstieg und Niedergang der römischen Welt (II.17.2), hrsg. W. Haase, H. Temporini, de Gruyter, Berlin 1981.

Philipp P. Fehl, Raphael as a Historian: Poetry and Historical Accuracy in the Sala di Costantino, „Artibus et Historiae” 1993, no 28.

Uwe Fleckner, "Le trésor de souffrance de l'humanité devient un bien humain”. Sarkis, Warburg et la mémoire sociale de l'art, [w:] Sarkis, Das Licht des Blitzes - Der Lärm des Donners, Museum Moderner Kunst Stiftung Ludwig, Wien 1995.

Jean Gagé, La théologie de la victoire impériale, „Revue Historique” 1933, no 1.

Maurizio Ghelardi, Aby Warburg. La lotta per lo stile, Aragno, Torino 2012.

Ernst Gombrich, Aby Warburg. An Intellectual Biography, Phaidon, Oxford 1986. Jürgen Habermas, Wyzwalajaca moc symbolicznego formowania. Humanistyczne dziedzictwo Ernsta Cassirera i Biblioteka Warburga, [w:] idem, Od wrażenia zmysłowego do symbolicznego wyrazu, tłum. K. Krzemieniowa, Oficyna Naukowa, Warszawa 2004.

Johann Gottfried Herder, Rozprawa o pochodzeniu języka, tłum. B. Płaczkowska, [w:] idem, Wybór pism, Ossolineum, Wrocław 1988.

Tonio Hölscher, The Transformation of Victory into Power: From Event to Structure, [w:] Representations of War in Ancient Rome, ed. S. Dillon, K.E. Welch, Cambridge University Press, Cambridge 2006.

Marcus A. Hurttig, Warburg Vortrag „Dürer und die italienische Antike”, [w:] idem, Die entfesselte Antike. Aby Warburg und die Geburt der Pathosformel, Hamburger Kunsthalle, Hamburg 2011.

Ernst H. Kantorowicz, Roman Coins and Christian Rites, http://www.archive.org/ stream/ernstkantorowicz00reel01\#page/n1057/mode/lup. 
Ernst H. Kantorowicz, The Sovereignty of the Artist: A Note on Legal Maxims and Renaissance Theories of Art, [w:] idem, Selected Studies, J.J. Augustin Publisher, New York 1965.

Roland Kany, Hermann Usener as Historian of Religion, „Archiv für Religionsgeschichte" 2004, Bd 6.

Roland Kany, Mnemosyne als Programm. Geschichte, Erinnerung und die Andacht zum Unbedeutenden im Werk von Usener, Warburg und Benjamin, Niemeyer, Tübingen 1987.

Gottfreid Korff, Kasten 117. Aby Warburg und der Aberglaube im Ersten Welkrieg, Tübinger Vereinigung für Volkskunde, Tübingen 2007.

Karl R. Krierer, Sieg und Niederlage: Untersuchungen physiognomischer und mimischer Phänomene in Kampfdarstellungen der römischen Plastik, Phoibos Verlag, Wien 1995.

Anne-Marie Leander-Touati, The Great Trajanic Frieze. The Study of a Monument and of the Mechanisms of Message Transmission in Roman Art, Paul Åströms Förlag, Stockholm 1987.

Jarosław Mikołajewski, Rzymska komedia, Agora, Warszawa 2011.

Erwin Panfosky, Ikonografia i ikonologia, tłum. K. Kamińska, [w:] idem, Studia z historii sztuki, PIW, Warszawa 1971.

Platon, Protagoras, tłum. L. Regner, PWN, Warszawa 1995.

Charlotte Schoell-Glass, Aby Warburg and Anti-Semitism, Wayne State University Press, Detroit 2008.

Jean Seznec, Diderot and 'The Justice of Trajan', „Journal of the Warburg and Courtauld Institutes" 1957, no 1-2.

Justyna Sprutta, Calcatio jako triumf Boga nad złem: szkic zagadnienia, „Studia Gnesnensia” 2016, nr 30.

Susan Sontag, Widok cudzego cierpienia, tłum. S. Magala, Karakter, Kraków 2010. Jakub Szczuka, Mnemosyne. Sztuka jako organ społecznej pamięci w pismach Aby Warburga, „Roczniki Humanistyczne” 1998, z. XLVI.

Hermann Usener, Götternamen, Versuch einer Lehre von der religiösen Begriffsbildung, Verlag for Friedrich Cohen, Bonn 1896.

Hermann Usener, Keraunos, ein Beitrag Religiöser Begriffsgeschichte, „Rheinisches Museum Für Philologie" 1905, Bd. 60.

Giambattista Vico, Nauka nowa, tłum. J. Jakubowicz, PWN, Warszawa 1966. Aby Warburg, Atlas obrazów Mnemosyne, red. M. Warnke, tłum. P. Brożyński i M. Jędrzejczyk, Narodowe Centrum Kultury, Warszawa 2015. 
Aby Warburg, Bilderreihen und Ausstellungen, hrsg. U. Fleckner, I. Woldt, Akademie Verlag, Berlin 2012.

Aby Warburg, Der Eintritt des antikisierenden Idealstils in die Malerei der Frührenaissance, [w:] idem, Werke in einem Band, hrsg. M. Treml, Suhrkamp, Berlin 2010.

Aby Warburg, Fragmente zur Ausdruckskunde, hrsg. U. Pfisterer, H.Ch. Hönes, De Gruyter, Berlin 2015.

Aby Warburg, Il primo Rinascimento italiano. Sette conferenze inedite, ed. G. Targia, Aragno, Torino 2013.

Aby Warburg, Narodziny Wenus i inne szkice renesansowe, tłum. R. Kasperowicz, Słowo/Obraz Terytoria, Gdańsk 2010.

Aby Warburg, Obrazy z terytorium Indian Pueblo w Ameryce Pótnocnej, tłum. P. Sosnowska, „Konteksty” 2011, nr 2-3.

Aby Warburg, „Per monstra ad sphaeram”. Sternglaube und Bilddeutung. Vortrag in Gedenken an Franz Boll und andere Schriften 1923 bis 1925, red. D. Stimili, C. Wedepohl, Dölling und Galitz, München - Hamburg 2008.

Aby Warburg, Piero della Francescas Constantinschlacht in der Aquarellkopie des Johann Anton Ramboux, [w:] L'Italia e l'arte straniera: atti del X Congresso Internazionale di Storia dell'Arte in Roma (1912), ed. A. Venturi, Maglione \& Strini, Roma 1922.

Martin Warnke, Der Leidschatz der Menschheit wird humaner Besitz, [w:] Die Menschenrechte des Auges. Über Aby Warburg, hrsg. W. Hofmann, Europäische Verlagsanstalt, Frankfurt am Main 1980.

Claudia Wedepohl, Aby Warburg und die Aquarellkopie des Johann Anton Ramboux nach Piero della Francescas „Konstantinsschlacht“ in Arezzo, [w:] Artium conjunctio: Kulturwissenschaft und Frühneuzeitforschung; Aufsätze für Dieter Wuttke, P. Schöner, G. Hübner, Koerner, Baden-Baden 2013.

Margaret A. Zaho, Imago Triumphalis: The Function and Significance of Triumphal Imagery for Italian Renaissance, Peter Lang, New York 2004.

Paul Zanker, I barbari, l'imperatore e l'arena. Immagini di violenza nell'arte romana, [w:] idem, Un'arte per l'Impero: Funzione e intenzione delle immagini nel mondo romano, Electa, Milano 2002. 


\section{Iconology of Suffering. Aby Warburg on Pictorial Symbolization and the Images of War}

In the book Regarding the Pain of Others Susan Sontag tackles the problem of war photography as a mean of mobilization of anti-war opposition. She mentions also the tradition of pictorial representations of 'disasters of war' as well as the western 'iconography of suffering'. In her erudite essay, Sontag chose to omit German 'Bildhistoriker', Aby Warburg (1886-1929). Warburg's concept of genesis of images from the spirit of suffering and his contribution to the study of visual aspects of war are the subjects of the present essay.

Keywords: Aby Warburg, suffering, images of war 